\title{
Klasycy i ich (nie zawsze) klasyczne dzieła
}

\section{Jurica Pavičić, Klasici hrvatskog filma jugoslavenskog razdoblja, Hrvtaski filmski savez, Zagreb, 2017, 303 s.}

Klasici hrvatskog filma jugoslavenskog razdoblja (2017) to zbiór dwunastu esejów poświęconych kilkunastu długometrażowym, zrealizowanym przez czołowych reżyserów chorwackich, filmom fabularnym z lat 1945-1990, a więc z okresu kinematografii jugosłowiańskiej ${ }^{1}$. Propozycja Juricy Pavičicia - historyka, krytyka filmowego i wykładowcy, od dawna realizującego się także w roli felietonisty oraz pisarza ${ }^{2}$ - obejmuje zarówno analizę pojedynczych tytułów, jak i szeroki komentarz dotyczący warunków produkcji filmowej oraz rzeczywistości społeczno-politycznej (często też gospodarczej) z okresu realizacji opisywanych dzieł. Na ich wybór wpłynął nie tylko zamiar, by na podstawie konkretnego materiału audiowizualnego prześledzić historię chorwackiej kinematografii w Jugosławii,

\footnotetext{
${ }^{1}$ Choć autorami wszystkich wybranych przez Pavičicia dzieł są reżyserzy chorwaccy (lub z Chorwacją związani), a większość filmów powstała w ramach chorwackiej produkcji kinematograficznej, trzy z nich nie wpisują się w ten schemat: Tri Ane (1959) Branka Bauera został wyprodukowany przez macedońską wytwórnię Vardar Film, Uzavreli grad (1961) Veljka Bulajicia przez serbską wytwórnię Avala Film, Banović Strahinja (1981) Vatroslava Mimicy zaś był finansowany przez trzy wytwórnie: chorwacką (Jadran Film), serbską (Avala Film) i niemiecką [RFN] (Neue Tele Film); w tym ostatnim odtwórcami głównych ról byli aktorzy rodzimi i zagraniczni, a scenariusz napisał jeden z kluczowych reżyserów serbskiej „czarnej fali”, Aleksandar Petrović.

${ }^{2}$ Jurica Pavičić pisze felietony i recenzje filmowe dla kilku dzienników i czasopism chorwackich („Slobodna Dalamcija”, „Jutarnji list”, „Vijenac”, „Zarez”). W 1998 roku ukazał się jego debiut literacki - thriller Ovce od gipsa, na podstawie którego Vinko Brešan zrealizował film Svjedoci (2003). Pavičić jest autorem kilku powieści, tomów opowiadań Patrola na cesti (2008) [na podstawie opowiadania o tym samym tytule został zrealizowany serial telewizyjny w reżyserii Zvonimira Juricia] i Brod $u$ dvorištu oraz zbioru felietonów Vijesti iz Liliputa (2001), Nove vijesti iz Liliputa (2011), a także monografii naukowych z zakresu filmoznawstwa (Postjugoslavenski film: stil i ideologija [2011]) i literaturoznawstwa (Hrvatski fantastičari - jedna književna generacija [2000]).
} 
ale również by - poprzez obrazy filmowe - lepiej przyjrzeć się zachodzącym w ciągu kilkudziesięciu lat zmianom w społeczeństwie chorwackim, jak bowiem twierdzi autor: „Film nie powstaje w próżni i nie może być w próżni interpretowany" (s. 10).

Większość spośród dwunastu tekstów prezentowanych w zbiorze była publikowana w czasopiśmie filmoznawczym „Hrvatski filmski ljetopis” (w latach 2002-2013), esej Geometrija intime: klasično i modernističko $u$ „Rondu” Zvonimira Berkovića ukazał się w 2016 roku w monografii Berković, „H-8... ”: film socijalističke katastrofe zaś, poświęcony filmowi $H-8 \ldots$ (1958) w reżyserii wybitnego operatora Nikoli Tanhofera został włączony do tomu zbiorowego Tanhofer (2016; obie monografie wydał Hrvatski filmski savez); krótsze wersje esejów o filmach Breza (1967) Ante Babaji i Banović Strahinja (1981) Vatroslava Mimicy ukazały się wcześniej w formie „książeczek” towarzyszących wydaniu tych filmów na DVD (w ramach serii „Zlatna kolekcija hrvatskog filma”). W czasie lektury Klasici hrvatskog filma jugoslavenskog razdoblja czytelnik ma okazję po raz pierwszy zapoznać się z interpretacją neorealistycznego obrazu Vlak bez voznog reda (1959), fabuły nietypowej dla autora znanych filmów partyzanckich Veljka Bulajicia, oraz inicjalnego tytułu z tzw. trylogii modernistycznej Vatroslava Mimicy - Prometej s otoka Viševice (1964).

Z wyjątkiem esejów dotyczących Zorana Tadicia i Veljka Bulajicia, w których autor opisuje dwa dzieła reżyserów (analizując Treći ključ [1983] Tadicia, nawiązuje do debiutu Ritam zločina [1981]; interpretacji Vlak bez voznog reda towarzyszy porównanie z dwa lata późniejszą realizacją Uzavreli grad [1961]), każdy tekst stanowi interpretację jednego tytułu wybranego autora. Dwóm twórcom Pavičić poświęca jednak więcej uwagi - w zbiorze można znaleźć odrębne analizy filmów Branka Bauera: Ne okreći se, sine! (1956) i Tri Ane (1959) (Rođenje revolucije iz starinskih nazora: „Ne okreći se, sine!” Branka Bauera; Nesreća i nakon nje: „,Tri Ane” Branka Bauera) oraz Vatroslava Mimicy: Prometej s otoka Viševice i Banović Strahinja (1981) (Autobiografija komunizma: „Prometej s otoka Viševice” Vatroslava Mimice; „Hamlet” na desetercu: „Banović Strahinja" Vatroslava Mimice) - z której to decyzji autor "tłumaczy się" w przedmowie, wskazując przede wszystkim na artystyczną, skłaniającą do wielokierunkowego odczytania różnorodność dorobku obu twórców. 
Biorąc pod uwagę tytuł książki, a zwłaszcza ujętych w nim „,klasyków” chorwackiego kina, zaskoczyć może brak dzieł, których „klasyczność" jest nie do podważenia. Spodziewając się ewentualnych zarzutów w tym względzie, autor wyjaśnia, skąd nieobecność: (1) Koncertu (1954) Branka Belana (absencję usprawiedliwiać ma istniejący już, „słynny” [s. 10] tekst Hrvoja Turkovicia Vrednovateljski obrat: recepcija „,Koncerta" nekad i danas); (2) wybitnego i w tamtym czasie nowatorskiego pseudodokumentu Živa istina (1972) Tomislava Radicia, który jednak według Pavičicia zdezaktualizował się; (3) partyzanckich produkcji Antuna Vrdoljaka (autor zbioru rezygnuje z pisania o tych filmach, gdyż swoich dzieł, z powodów politycznych, „wyrzekł się sam reżyser” [s. 10]). Arbitralny wybór filmoznawcy obejmuje jednak również te chorwackie produkcje, które swego czasu zostały wyjątkowo dobrze przyjęte przez krytykę i publiczność, a nadany im status filmów klasycznych czy wręcz kultowych przetrwał do dzisiaj, mimo transformacji polityczno-ideologicznych i przemian filmowych gustów. Do tej grupy, spośród dzieł wybranych przez Pavičicia, należą na przykład $H-8$... Nikoli Tanhofera, Breza Ante Babaji czy Lisice (1969) Krsto Papicia.

Eseje ułożone są w porządku chronologicznym według dat powstania filmów: zbiór otwiera socrealistyczna komedia Krešy Golika Plavi 9 z 1950 roku, zamyka zaś zrealizowany w 1983 roku ,thriller z elementami fantastyki grozy" (s. 259) - Treći ključ Zorana Tadicia, reżysera, który w historii chorwackiego kina zapisał się przede wszystkim jako wybitny dokumentalista. Te dwa tytuły, będące ramą zbioru, mogą wywołać usprawiedliwiony niepokój czytelnika: trudno bowiem - porównując je z innymi dziełami tych samych reżyserów, choćby z bijącym rekordy popularności, pierwszym musicalem chorwackim Tko pjeva, zlo ne misli (1970) Golika czy kryminałem Tadicia z 1986 roku San o ruži - nazwać filmy wybrane przez Pavičicia klasykami chorwackiej kinematografii. Podobne wątpliwości może wzbudzić wybór materiału do analizy w przypadku twórczości Vatroslava Mimicy i Veljka Bulajicia - i tu autor zdecydował się opisać filmy albo niekoniecznie reprezentatywne dla twórczości danego twórcy (V. Bulajić), albo będące co prawda propozycją wartościową, lecz w porównaniu z mistrzowskimi realizacjami tego samego reżysera stanowiącą wskazanie mniej oczywiste (V. Mimica). Jednak i tego rodzaju niepokój widza-czytelnika Pavičić neutralizuje, nakreślając w przedmowie motywy, 
które zadecydowały o takiej właśnie selekcji filmowego materiału. Autor bowiem zdecydował się na tytuły umożliwiające prezentację konkretnych poetyk i stylów obecnych w dziejach chorwackiego filmu okresu jugosłowiańskiego. Przyglądając się poszczególnym realizacjom, dał obraz wielości kierunków, którymi podążała opisywana kinematografia w ówczesnych warunkach historycznych. Zgodnie z przyjętą zasadą, analiza dwunastu tytułów (dziesięciu reżyserów) pozwala zarysować kolejne etapy jej rozwoju wraz z wewnętrznym zróżnicowaniem. W zbiorze można więc znaleźć filmy reprezentatywne dla różnych nurtów, wpływów i prób legitymizacji danej poetyki: powojenny socrealizm, narracyjne kino klasyczne, tytuły „pograniczne”, będące zapowiedzią nowych tendencji w chorwackiej kinematografii, produkcje modernistyczne, chorwacką wersję stylu neorealistycznego, film historyczny i gatunkowy czy reprezentację generacji filmowców tzw. praskiej szkoły.

Każdy tekst cechuje podobna konstrukcja: eseje rozpoczyna scenopis zapoznający czytelnika z akcją i bohaterami filmu, po czym autor przedstawia sylwetkę reżysera, okoliczności realizacji dzieła oraz jego recepcję (zarówno wśród krytyki, jak i publiczności), następnie przechodzi do interpretacji, która dotyczy nie tylko samej struktury audiowizualnej, ale niejednokrotnie również kontekstów znacznie szerszych, np. ideologicznych, politycznych, społecznych. Przez pryzmat filmowego obrazu Pavičić komentuje szereg zjawisk obecnych w chorwackim społeczeństwie w Jugosławii, co sygnalizują już frazy współtworzące tytuły niektórych tekstów, jak choćby: Lopta i čekić: kolektiv i individua u Golikovom „Plavi 9”, Autobiografija komunizma: „Prometej s otoka Viševice” Vatroslava Mimice, Kuga u komunističkoj Tebi: „Treći ključ” Zorana Tadića. Komentując wymienione filmy, autor wskazuje na zjawiska, z którymi borykały się i władza, i społeczeństwo.

Analiza Plavi 9 (1950) pozwala stwierdzić, że lata 50. ubiegłego wieku to czas, w którym jugosłowiański komunizm musiał nadać swej strukturze ideologicznej rys indywidualizmu, wynikającego z wprowadzenia elementów gospodarki wolnorynkowej (co z kolei dało początek konsumpcyjnemu stylowi życia, s. 28), sprzeczność zaś między „hedonistycznym indywidualizmem a etyką kolektywu” (s. 29) staje się „alegorią dwóch możliwości rozwoju komunistycznego projektu totalitaryzmu" (s. 29). Prometej s otoka Viševice otwiera według Pavičicia dyskusję, która 
z biegiem lat nie straciła na znaczeniu, a dzisiaj, w dobie globalizacji, jest być może nawet bardziej aktualna niż ponad pół wieku temu. W jego rozumieniu film przedstawiający bohatera, który dążąc do modernizacji wyspy Viševice spotyka się z oporem mieszkańców, a jego bezowocne starania i upór przywołują skojarzenie z Syzyfem, formułuje dwa istotne i uniwersalne pytania: co ma większą wartość - demokracja czy modernizacja? I czy modernizację wolno przeprowadzić mimo braku zgody większości, a tym samym: czy demokrację można wartościować pozytywnie, nawet jeśli wola większości prowadzi do stagnacji i regresji (s. 146-147)? Jeszcze inny przypadek: Treći ključ (1983), porównywany z Lokatorem (1976) Romana Polańskiego, to film o „grzechu mieszczaństwa” (s. 275), skorumpowanej klasie średniej jugosłowiańskiego społeczeństwa, które w latach 80. funkcjonowało w ciągłym konflikcie: z jednej strony (po odczuwalnej liberalizacji w latach 60.) był to moment, w którym ,reżim już nie ukrywał swojego represywnego i niedemokratycznego charakteru" (s. 274), z drugiej jednak lata 70. i początek kolejnej dekady były w Jugosławii czasem dobrobytu, rozkwitu konsumpcyjnego stylu życia, a w rezultacie - wzrostu poczucia stabilności i bezpieczeństwa, co „stępiło potrzebę oporu” (s. 274). Autor, widząc pewne niedociągnięcia filmu (na które zwracała uwagę już ówczesna krytyka, wyżej oceniając debiut fabularny Tadicia), podkreśla innowacyjność w sposobie formułowania krytycznego komentarza społecznego towarzyszącego wielu produkcjom jugosłowiańskim tego okresu. Realizacja horroru z elementami fantastycznymi pozwoliła reżyserowi w aluzyjny sposób pokazać niepokój, którego doświadczają nie tylko przedstawiciele klasy średniej, ale i cała, przeżywająca szereg kryzysów, jugosłowiańska federacja. Według interpretacji Pavičicia (inaczej niż w przypadku debiutu Ritam zločina) to nie nadprzyrodzone zjawiska wpływają tu na zachowania społeczne, ale odwrotnie: te ostatnie generują występowanie niezwykłych fenomenów, które uniemożliwiają bohaterom normalną egzystencję. W ten sposób Tadić obrazuje chorobę, tytułową dżumę, która dotyka klasę średnią: żyjącą w komforcie materialnym, lecz odczuwającą dyskomfort psychiczny wynikający ze sprzeniewierzenia się zasadom moralnym. W tym miejscu warto wrócić do eseju otwierającego zbiór. Z filmu Plavi 9 autor wyczytał komunikat o dylemacie władzy, który musiał skończyć się próbą połączenia wartości komunistycznych z ideą indywidualizmu, towarzyszącą wolnemu rynkowi. Treći ključ, obraz 
społecznej sytuacji lat 80., wskazuje już na konsekwencje tej decyzji, będącej jednym ze źródeł degradacji etycznej - nie u pojedynczych osób, a całej warstwy społecznej (klasy średniej).

Pavičić, zamykając ostatni esej, odnosi się do poetyki filmu Tadicia, który inspirując się klasykami kina gatunkowego, odszedł od dwóch dominujących w tym czasie w chorwackiej kinematografii trendów (kino autorskie z jednej strony, film zaangażowany społecznie z drugiej), a przy tym nie zrezygnował z krytycznego komentarza wobec kondycji chorwackiego społeczeństwa (co ówczesna krytyka zignorowała). Według autora eseju tego rodzaju realizacje mogłyby zapoczątkować nowy nurt w tradycji jugosłowiańskiej kinematografii (obecny w tym czasie w kinie europejskim). Ewentualną jego kontynuację uniemożliwił jednak zbliżający się upadek projektu jugosłowiańskiego: „Zaledwie kilka lat po «dżumie» Tadicia znikną komunistyczne «Teby». Dla chorwackiego filmu rozpocznie się nowy i inny okres, znacznie bliższy późnym latom 40. niż końcówce lat 80. Rozpocznie się czas, w którym kinematografia ponownie pełni utylitarną, a nawet agitacyjno-propagandową funkcję, w którym od filmowców oczekuje się polityczności, zaangażowania i bezpośredniości - tym razem nie w imię ideologii i klasy, a w imię młodej narodowości” (s. 278).

Choć nie wszystkie wybrane przez Pavičicia filmy mają status klasyków chorwackiej kinematografii, wszystkie z pewnością przedstawiają wysoki poziom artystyczny, a każdy tytuł jest reprezentatywny dla określonego zjawiska obecnego (bądź jedynie zapoczątkowanego) w historii chorwackiego filmu. Klasici hrvatskog filma jugoslavenskog razdoblja to zbiór tekstów, które na zasadzie synekdochy przedstawiają wizerunek pewnej kultury filmowej, ale też - co dla pisarstwa filmoznawczego nie jest regułą - dają wyobrażenie autorskiej interpretacji przemian społecznych (tu: dotyczących społeczeństwa chorwackiego drugiej połowy XX wieku). Erudycyjne analizy Pavičicia okazują się dla autora świetną okazją, by na ekranie szukać wiedzy o źródłach dzisiejszej kondycji społeczno-kulturowej Chorwatów. Na takim podejściu zyskują też same filmy: proponowane odczytania stawiają je często w nowym, zaskakującym świetle, a dyskusje podejmowane z niegdysiejszymi obserwacjami krytyków aktualizują ich znaczenie, kreując możliwość ponownej recepcji. 